\title{
Mid and Late Holocene Forest Fires and Deforestation in the Subalpine Belt of the Iberian Range, Northern Spain
}

José M. García-Ruiz ${ }^{1}$ (D) http://orcid.org/0000-0002-8535-817X; e-mail:humberto@ipe.csic.es Yasmina Sanjuán ${ }^{1}$ (D) http:// orcid.org/0000-0003-4400-4444; e-mail:ysanjuan@ipe.csic.es Graciela Gil-Romera ${ }^{1}$ (D) http:// orcid.org/0000-0001-5726-2536; e-mail:graciela.gil@ipe.csic.es Penélope González-Sampériz ${ }^{1}$ (D) http:// orcid.org/0000-0002-5097-1468; e-mail: pgonzal@ipe.csic.es

Santiago Beguería 2 (D) http://orcid.org/0000-0002-3974-2947; e-mail: sbegueria@eead.csic.es José Arnáez ${ }^{3}$ (D) http:// orcid.org/0000-0001-8248-5272; e-mail: jose.arnaez@unirioja.es Paz Coba-Pérez 4 (D) http:// orcid.org/0000-ooo1-7258-4576; e-mail: pcoba@cieco.unam.mx Amelia Gómez-Villar 5 (D) http:// orcid.org/0000-0002-0061-8017; e-mail: agomv@unileon.es Javier Álvarez-Martínez ${ }^{6}$ (D) http:// orcid.org/ 0000-0002-0861-2840; e-mail: gestion@iaf.uva.es

Noemí Lana-Renault 3 (D) http:// orcid.org/ 0000-0002-0272-2504; e-mail: noemi-solange.lanarenault@unirioja.es

Estela Pérez-Cardiel 7 (D) http://orcid.org/0000-0002-4451-6864; e-mail:epcardiel@gmail.com Carlos López de Calle 8 (D) http://orcid.org/0000-0001-6652-7030; e-mail:00clcc@gmail.com

1 Instituto Pirenaico de Ecología, Consejo Superior de Investigaciones Científicas (IPE-CSIC), Campus de Aula Dei, P.O. Box 13.034, 50.080-Zaragoza, Spain

2 Estación Experimental de Aula Dei, Consejo Superior de Investigaciones Científicas (EEADCSIC), Campus de Aula Dei, P.O. Box 13.034, 50.080-Zaragoza, Spain

3 Area of Physical Geography, University of La Rioja, 26.004-Logroño, Spain

4 Centro de Investigaciones en Geografía Ambiental, Universidad Nacional Autónoma de México, Unidad Morelia, Antigua Carretera a Pátzcuaro 8701, 58190-Morelia, Michoacán, México

5 Departamento de Geografía y Geología, Facultad de Filosofía y Letras, Universidad de León, Campus de Vegazana, 24.071-León, Spain 
6 Departamento de Ingeniería Agrícola y Forestal, Universidad de Valladolid, Campus La Yutera, 34.071-Palencia, Spain

7 Department of Geography and Land Management, University of Zaragoza, 50.009-Zaragoza, Spain

8 Freelance archaeologist, Avda. Colón, 4, 26003-Logroño, Spain

Abstract: The conversion of subalpine forests into grasslands for pastoral use is a wellknown phenomenon, although for most mountain areas the timing of deforestation has not been determined. The presence of charcoal fragments in soil profiles affected by shallow landsliding enabled us to date the occurrence of fires and the periods of conversion of subalpine forest into grasslands in the Urbión Mountains, Iberian Range, Spain. We found that the treeline in the highest parts of the northwestern massifs of the Iberian Range (the Urbión, Demanda, Neila, and Cebollera massifs) is currently between 1500 and $1600 \mathrm{~m}$ a.s.l., probably because of pastoral use of the subalpine belt, whereas in the past it would have reached almost the highest divides (at approximately 2100-2200 m a.s.l.). The radiocarbon dates obtained indicate that the transformation of the subalpine belt occurred during the Late Neolithic, Chalcolithic, Bronze Age, Iron Age, and Middle Ages. Forest clearing was probably moderate during fires prior to the Middle Ages, as the small size of the sheep herds and the local character of the markets only required small clearings, and therefore more limited fires. Thus, it is likely that the forest recovered burnt areas in a few decades; this suggests that the management of the forest and grasslands following a slash-and-burn system. During the Middle and Modern Ages deforestation and grassland expansion affected most of the subalpine belt and coincided with the increasing prevalence of transhumance, as occurred in other mountains in the Iberian Peninsula (particularly the Pyrenees). Although the occurrence of shallow landslides following deforestation between the Neolithic and the Roman Period cannot be ruled out, the most extensive shallow landsliding processes would have occurred from the Middle Ages until recent times.

Keywords: Forest fires; Holocene; Subalpine grasslands; Shallow landslides; Landscape changes; Iberian Range

\section{Introduction}

Mountain areas have altitudinal belts that are defined by their biota and anthropogenic management characteristics, typically associated with the optimization of the use of 
natural resources (i.e. grasslands, timber, agricultural fields) (García-Ruiz et al. 2015). Each altitudinal belt occupies a specific place in the management system, which is organized according to population density, culture, market options, and environmental characteristics. Commonly, there is a low altitude montane belt, where husbandry activities prevail, a mid montane belt, where logging alternates with agricultural fields (occasionally under shifting agriculture), a high montane belt dominated by logging, and a subalpine belt used for livestock during the summer (García-Ruiz and Lasanta 1990). At higher altitudes the alpine belt is only used for hunting or recreational activities, and sometimes mining. The way and intensity with which such belts are managed have direct consequences for geomorphic processes, soil redistribution, and runoff generation (García-Ruiz et al. 2015). There have been relatively few reports on landscape evolution and soil erosion in the subalpine belt of the European mountains. However, an increasing number of studies have examined lacustrine and peatbog sediments, thus contributing to the identification of the main steps in forest clearing and the transformation of subalpine belts into grasslands. Of particular relevance are those of Montserrat (1992), Galop and Jalut (1994), Miras et al. (2007, 2010), Ninot et al. (2008), Bal et al. (2011), and Pérez-Sanz et al. (2013) in the Central Pyrenees; and Tinner et al. (1999, 2003), Schmidt et al. (2002), Blarquez et al. (2010), Colombaroli et al. (2010, 2013), Guiguet-Covex et al. (2011), Roepke and Krause (2013), and Walsh et al. (2014) in the Alps. These studies have all considered the important role of human activities, in most cases since at least the mid Holocene, in changing the structure and composition of forests in the subalpine belt, and in the use of large grassland areas to feed transhumant livestock in summer (e.g. García-Ruiz and Valero-Garcés 1998; Guiguet-Covex et al. 2011). Although some studies have continued to emphasize the role of climate in such changes, particularly through its influence as a cause of wildfires (Daniau et al. 2012; Marlon et al. 2013; Gil-Romera et al. 2014), it is widely acknowledged that since the mid Holocene the impact of human-induced fires, especially through slash-and-burn practices, may have been greater than large climateinduced fire events (Colombaroli et al. 2010; Bal et al. 2011).

The current subalpine landscape in the mountains of the Iberian Peninsula is characterized by extensive grasslands, alternating with patches of shrub (Calluna vulgaris and Erica cinerea on acid soils, and Juniperus communis on alkaline soils) and open forests of Pinus sylvestris and P. uncinata, the latter occurring at the upper boundary of the subalpine belt in the northern mountains. This landscape is a 
consequence of the interactions between climate and grazing activities, which have progressively reduced the number of trees and the altitude of the treeline, and the almost complete loss of krummholz areas. Changes in the altitude of the upper forest limit have been highly variable as a result of past management systems (García-Ruiz et al. 1990). The consequences of an altitudinal reduction in the treeline and deforestation can be an altitudinal reduction in solifluction processes (Höllermann1985), the triggering of shallow landslides (García-Ruiz et al. 2010), and the occurrence of a variety of erosion processes, including gullying and extensive development of gelifluction terracettes (García-Ruiz and Puigdefábregas 1982). Snow accumulation and snowmelt are also directly influenced by the conversion of forests into grasslands (Alvera and Puigdefábregas 1985; López-Moreno and García-Ruiz 2004; Lana-Renault et al. 2011). Geomorphological and hydrological changes because of past land cover disturbances demonstrate the fragility of the subalpine belt, and have conditioned forest reestablishment following the recent decline in livestock numbers and grazing activities. This is a major environmental issue in the short term, because climate change is affecting snow accumulation and the timing of snowmelt (e.g. López-Moreno and García-Ruiz 2004; Stewart 2009; Hantel et al. 2012; Marty and Meister 2012; Sharma et al. 2013), and is indirectly driving forest re-establishment in the subalpine belt.

During a field study of geomorphic processes related to the transformation of subalpine forests into grasslands in the northwestern massifs of the Iberian Range, we found various charcoal fragments in the soil profiles of shallow landslide scars. This provided the opportunity to date the occurrence of paleo-fires and to clarify the main features of evolution of the landscape.

This report is the first concerning the occurrence of prehistoric and historic forest fires in the subalpine and upper montane belts of the Iberian Range, in the northern Iberian Peninsula. Its findings contribute to interpretation of the evolution of the landscape in a grassland area traditionally characterized by intensive summer grazing by many thousands of sheep. We also reviewed regional palaeoenvironmental studies, and provide information on the characteristics of the subalpine areas transformed into grasslands, and the main geomorphological impacts of this process.

\section{Study Area}

The Urbión massif is one of the highest mountain areas of the Iberian Range, in the northeastern sector of the Iberian Peninsula (Figure 1). The massif (maximum peak 
height $2228 \mathrm{~m}$ ) is mainly composed of Upper Jurassic and Lower Cretaceous small quartz conglomerate, and red mudstone and limestone that were deposited in a large delta. The alpine tectonics folded and faulted these materials, resulting in a monoclinal relief with the abrupt front facing north. The front was affected by Pleistocene glaciation, with the development of cirques, U-shaped valleys (up to 6-7 km in length), and moraine-dammed lacustrine deposits and tills. The lowest tills in the Urbión Valley are located at $1270 \mathrm{~m}$ a.s.l. (García-Ruiz et al. 1998).

Climate data are only available from observatories located on the southern face of the massif, at approximately 1100-1150 m a.s.l. These have recorded a temperature increase in the last 60 years; thus, the mean annual temperature at Vinuesa was $7.7^{\circ} \mathrm{C}$ for the period $1957-1965$, and $9.6^{\circ} \mathrm{C}$ for the period 1990-2001. In general, the mean annual temperature has increased by $1.1^{\circ} \mathrm{C}$, and particularly in winter (average $1.3^{\circ} \mathrm{C}$ ) (García de Celis et al. 2008). A dendroclimate study in the neighboring Cebollera Range confirmed that temperature increased significantly during the 20th century (Camarero Martínez and Gutiérrez Merino 2008). Mean annual precipitation exceeds $900 \mathrm{~mm}$ above $1000 \mathrm{~m}$ a.s.l., and is probably $1500-1600 \mathrm{~mm}$ in the main divide, as estimated by Arnáez Vadillo (1987) for the neighboring Demanda Range. Precipitation has declined slightly since the mid-20th century, particularly between November and March (García de Celis et al. 2008).

Plant cover is dominated by extensive $P$. sylvestris forests on the south-facing slope, whereas the northern face has a complex mosaic of P. sylvestris and Fagus sylvatica forests, grasslands and shrubs with heathers of $C$. vulgaris and E. cinerea, and Vaccinium myrtillus and J. communis, even on soils developed on limestone substratum. The area has been used in summer for transhumant sheep herds, with two notable periods of intense activity: the 15th century, and the period between the end of the 17th and the end of the 18th centuries, coinciding with an international increase in wool demand (Diago Hernando 2002). A crisis occurred in the transhumance system at the beginning of the 19th century, resulting in local populations increasing the cultivated area (Moreno Fernández 1994). In 1792 the main two villages (Viniegra de Abajo and Viniegra de Arriba) accounted for 17,169 (262 per km²) and 19,100 (497 per km²) sheep, respectively (Moreno Fernández 1996). At present the number of sheep is only 840 and 2690 in total, respectively. The increase in temperature and the decline in grazing activities explain the recent increase in the altitude of the treeline; on the south- 
facing slope of the Urbión Range in 1956 it was located at $1866 \mathrm{~m}$, but it was at $1900 \mathrm{~m}$ in 2006 (García de Celis et al. 2008).

\section{Methods}

The Ormazal Valley (total area 2449 ha), which is upstream of Viniegra de Arriba, was selected for sampling and detailed study. The valley has a small glacial cirque in the headwater area, karstic activity on the limestone outcrops, relatively gentle slopes (in general, < 30\%), wide divides, and large areas covered with subalpine grasslands intensively disturbed by shallow landslides. The valley ranges in altitude from $1240 \mathrm{~m}$ to $1887 \mathrm{~m}$ a.s.l.

A map showing the location of the active scars of shallow landslides was developed using the 2006 orthophoto available from the National Geographic Institute of Spain. Data on the topographical features of the scars (altitude, aspect, and gradient) were recorded.

Aerial photos from 1956, the 2006 orthophoto, and a GIS were used to develop the corresponding vegetation maps. The resolution of digitized maps was $18 \times 18 \mathrm{~m}$ per pixel.

A field campaign in summer 2014, and analysis of aerial photos and orthophotos enabled the shallow landslide scars in the Ormazal Valley to be identified, and their distribution determined in relation to plant cover and altitude.

Soil samples (15) selected from the landslide scars were sieved to isolate microcharcoal for radiocarbon analysis to determine a chronological framework. A total of 8 accelerator mass spectrometry (AMS) radiocarbon dates were obtained from various profiles in the study area; these were calibrated using Calib v. 7.02 (Stuiver and Reimer 1993) using the latest calibration datasets (Reimer et al. 2013).

\section{Results}

\subsection{Plant cover characteristics}

Figure 2a and Table 1 show the 1956 vegetation cover map and data, respectively. Grasslands (34\%) and shrub communities (31.9\%) were the most extensive types of vegetation cover, with the former dominating in the eastern sector of the valley and the latter in the western and southern sectors. Most of the shrub areas were probably occupied by grasslands in previous decades (perhaps for centuries), when the transhumance system was at its height. Open forests dominated by $P$. sylvestris 
occupied small patches in the western and southern sectors of the valley (9.8\%). Dense forests composed mainly of F. sylvatica covered only $1.8 \%$ of the area, and were exclusively located in the northernmost sector of the valley. Eroded areas occupied $18.4 \%$ of the study area, and seem to be spatially related to grasslands, forming small patches having irregular borders. A small area (0.7\%) in the northwest of the valley was still cultivated, and was surrounded by abandoned fields (2.9\%). In total, the grasslands, shrubs, and eroded areas represented $84 \%$ of the study area in 1956 . This can be assumed to be the minimum area occupied by grasslands at the time of maximum livestock pressure.

Figure $2 \mathrm{~b}$ shows the plant cover map for 2006, and the proportion occupied by each vegetation class is shown in Table 1 . These demonstrate that a remarkable decline had occurred in the areas of grassland (25.4\%) and shrubs (23.9\%) since 1956 and that there had been an increase in the dense forest area (16.3\%). Dense forest of P. sylvestris was particularly evident in the southernmost part of the valley, and in small patches of the western sector, whereas there had been a moderate increase in the area of dense deciduous forests in the northern sector. Also noteworthy are the decline in open forest area (8\%) and the presence of two areas afforested with $P$. sylvestris (4\%). The eroded areas were similar in extent (17.8\%), and the cultivated areas had disappeared and been replaced by abandoned fields.

\subsection{Fire history records}

As noted above, eight charcoal fragments from soil profiles in shallow landslide scars were dated. Figure 3 shows the location of the charcoal fragments, and Table 2 provides data for each fragment and the altitude at which it was collected. The fragments represent the occurrence of local or more general fires of natural or humaninduced origin. A wide variety of ages were established among the fragments.

(i) The oldest recorded fires corresponded to the Late Neolithic (5630 cal yr BP) and the Chalcolithic (4911, 4858, and 3962 cal yr BP).

(ii) Some fire remains corresponded to the Bronze Age (3162 cal yr BP).

(iii) Two charcoal remains indicated fires that occurred during the Iron Age (2234 and 2034 cal yr BP).

(iv) Only one charcoal fragment could be associated with the Middle Ages (1116 cal yr $\mathrm{BP})$. 
No relationship was found between the dates established for fire occurrence and topographic variables. In fact, fragments having highly contrasting dates were found in the same area of the valley at similar altitudes. Consequently, deforestation was not found to be associated with altitude or topographic aspect. The altitudinal range of the charcoal samples was 1738-1859 m a.s.l.

\subsection{Spatial distribution of shallow landslides}

Figure 4 shows the location of shallow landslides in the Ormazal Valley, based on the orthophoto for the year 2006. The landslides were characterized by a semicircular crown or scar of highly variable width (5-25 m) (Figure 5). Bedrock and abundant detached rock fragments were visible in the area directly affected by landsliding, and gelifluction terracettes had develop in the remnants of the soil. In most cases the landslide plane coincided with the contact between the $\mathrm{C}$ soil horizon and the bedrock (i.e. between 40 and $60 \mathrm{~cm}$ depth). The soil depth varied as a function of topography; 80-90 cm deep on concave slopes; 40-60 cm on straight slopes; and approximately 35-40 cm on convex slopes.

A total of 270 landslide scars were identified in the Ormazal Valley (10.7 scars

$\mathrm{km}^{-2}$ ). Most of the scars occurred in the highest areas, almost always above $1500 \mathrm{~m}$ a.s.l., and particularly between 1600 and 1950 m (185 landslide scars, 68\% of the total) in the subalpine belt. The presence of shallow landslides was particularly related to grasslands (58\%) and eroded hillslopes having small patches of remaining soil (28\%). Shrub cover areas contained $10 \%$ of the scars, whereas few (2\%) were present in forest areas, including natural forests and afforested areas. The density of landslides was 22.8 per $\mathrm{km}^{2}$ in grassland areas, 17 per $\mathrm{km}^{2}$ in the eroded areas, 4 per $\mathrm{km}^{2}$ in shrub areas and 1 per $\mathrm{km}^{2}$ in forest areas. It is noteworthy that the landslide scars tended to have an aggregated spatial distribution (Figure 6).

\section{Discussion and Conclusions}

Extensive deforestation, aimed at creating new pastures for summer transhumant livestock, occurred in the ancient past at altitudes exceeding $1500 \mathrm{~m}$ a.s.l. in the northwest Iberian Range, affecting the subalpine belt and upper sectors of the montane belts. Forest clearing began in Neolithic times, and persisted until the present because of the grazing system, although the number of sheep flocks that reach the upper part of the mountains has clearly declined in recent decades. The golden period of transhumance 
probably occurred during the 15th century, and between the end of the 17th and the end of the 18th centuries (Diago Hernando 2002). The recent decline in the size of the total sheep flock has changed the landscape stability, with a marked trend of transformation of grasslands into shrubs, and ultimately into dense forests (Sobrón García 1987). The importance of transhumant livestock can be deduced from the fact that more than $80 \%$ of the study area comprised grasslands, shrubs, or eroded areas during the 1950s. We hypothesize that the eroded areas were covered by deep soils in the past, and they were eroded following deforestation, based on the activity of shallow landslides in the areas covered by grasslands. This process was similar to those observed in the Pyrenees (García-Ruiz et al. 2015) and the Alps (Roepke and Krause 2013).

The oldest charcoal fragments were obtained from soils affected by landsliding. Fires occurred during Late Neolithic times (5630 cal yr BP) and the Chalcolithic (50004000 cal yr BP), and also during the Bronze and Iron ages and the Middle Ages, indicating that fire activity has been a constant since the Neolithic, and suggesting ancient landscape disturbance for grazing purposes. Human-induced fires probably affected small areas, particularly during the Neolithic, Chalcolithic and Bronze ages, as small flocks managed for limited local markets would have required only small extensions of pasture area. Nevertheless, extensive uncontrolled fires would also have occurred. Studies of archaeological sites in mountains of northern Spain have shown that specialization in livestock exploitation has occurred since at least $5300 \mathrm{cal}$ BC (e.g. Els Trocs Cave, Central Pyrenees; Rojo Guerra et al. 2013). The main consequence of this fire activity was a reduction in the altitude of the timberline, which would have been at approximately $2100 \mathrm{~m}$ a.s.l. but at present forms an uneven boundary at 1600$1850 \mathrm{~m}$ a.s.l. A similar evolution occurred in the Pyrenees, where the potential timberline would be located between 2300 and $2400 \mathrm{~m}$ a.s.l. (Ninot et al. 2008), in contrast to its present location at 1650-1800 m.

Various reports on the evolution of Holocene paleoenvironments have noted that human disturbance of the landscape dates to the Neolithic, as deduced by the presence of human indicators in pollen lacustrine sequences, as well as the occurrence of archaeological sites coinciding with changes in land cover (Carrión et al. 2007; Colombaroli et al. 2008; Gil-Romera et al. 2010). Nevertheless, some of these changes have occurred in parallel with climate fluctuations (Marlon et al. 2013), such that it is not easy to discriminate between anthropogenic and climatic forcings in explaining landscape evolution (Marlon et al. 2009; Pérez-Sanz et al. 2013). This problem is 
exacerbated in high mountain areas, where the impact of human activities since the Neolithic has been reduced to clearing of small forest patches and the grazing of small flocks in summer. Unfortunately, there is almost no information for this study area on landscape changes from lacustrine sequences, or archaeological evidence prior to the Roman Period. Analysis of the base of the lacustrine deposit in a sedimentary sequence from Nava Lake (Cebollera Range, near the Urbión Mountains) showed that the plant cover was dominated by grasslands related to local forest fires, as suggested by the presence of abundant large charcoal fragments (Gil García et al. 1996), although no radiocarbon dates were available. The peatbog of Hoyos de Iregua (1780 m a.s.l.), also in the Cebollera Range, shows a trend of forest decline since $5060 \pm 90 \mathrm{yr} \mathrm{BP}$, indicating the occurrence of forest clearings in the immediate area of the bog (Gil García et al. 2002; López de Calle and Tudanca 2014). Nine dolmens have been excavated in the Cebollera Range, and a similar number has been identified. These have been dated between 6000 and $3500 \mathrm{cal}$ yr BP, the period covering the Neolithic and the transition to the Chalcolithic (López de Calle and Pérez Arrondo 1995; López de Calle and Tudanca 2014). Unfortunately, all the sites involved are located below $1400 \mathrm{~m}$ a.s.l. (Barrios Gil 2005) and are quite far from the subalpine belt. However, they confirm the occurrence of the first agro-pastoral societies in the area (López de Calle et al. 2001), which probably used the subalpine belt during summer for their small sheep flocks, including landscape clearing through selective fires. This is consistent with the oldest fires (ca. 5600 years BP) recorded in the present study. Landscape changes would have continued during the Bronze and Iron ages, and probably during the Roman Period. This would have been at a relatively low intensity, probably with forest clearing alternating with forest re-colonization in distinct areas, as suggested by the different ages of the charcoal fragments.

The Middle and Modern Ages probably represent a change in the characteristics of landscape transformation, with intensification of sheep transhumance and the entry of Iberian Peninsula wool production into international markets. The northern massifs of the Iberian Range (the Neila, Urbión, Demanda, and Cebollera massifs) were particularly affected by these processes, which resulted in the grazing of thousands of sheep, and generalized deforestation (Diago Hernando 2002). A study of sedimentary sequences from four lakes in the Urbión Range (Gómez-Lobo 1993), which provides information on the period since $15510 \pm 90 \mathrm{BP}$, reported no evidence for human influence prior to $560 \mathrm{BP}$, although a decline in arboreal pollen was detected after ca. 
4500 yr BP. In the neighboring Cebollera Range, a study of the Ciega Lake also dated the beginning of forest degradation at ca. $560 \pm 80 \mathrm{yr} \mathrm{BP}$, coinciding with the remarkable presence of ruderal taxa and the substitution of pine for deciduous forests (Gil García et al. 1995). In the Grande Lake (Neila Range, immediately westward of the Urbión Mountains), Vegas (2007) found three main periods of higher water levels: 6000-5500; 4100-3500; and 750-650 cal yr BP. The high water levels during the two former periods had a climatic origin. The latter period was characterized by a decline in the area of forest, which was attributed to more intense human activity in the high mountain areas. Therefore, there is general agreement that extensive transformation of the landscape of the subalpine belt of the Iberian Range has occurred since the Middle Ages. Nevertheless, forest loss probably intensified during the 18th and 19th centuries, coinciding with the crisis of the transhumance system, the decline of textile industries, and the increase in population density (Gómez Urdáñez 1986). This forced the local stock breeders to expand their flocks, which required the use of local resources. Similarly, in some Pyrenean valleys the forests were replaced by cultivated fields and subalpine grasslands, resulting in changes in geomorphic processes and fluvial channel dynamics (Gómez-Villar et al. 2014; Sanjuán et al. 2014). A diversity of information on the beginning of human activities in the northern massifs of the Iberian Range suggests that fires were small and localized, and were associated with slash-and-burn systems. The use of fire as a tool to manage forest clearing did not commence until the Middle Ages, concurrent with access to larger markets.

Studies of other Spanish mountain areas confirm the importance of human activity in changing the spatial organization of forests and grasslands in subalpine areas during the Mid and Late Holocene (Morales-Molino et al. 2011; Berrocal et al. 2014). Pérez-Díaz et al. (2014) reported the emergence of anthropogenic palynomorphs during the Early Neolithic (5500-4500 cal yr BC) in the western Pyrenees. Rull et al. (2011) showed that human activity was the main driver of Holocene land cover changes in the southern Pyrenees during the last two millennia. Thus, study of a peatbog at $2180 \mathrm{~m}$ a.s.l. in the Madriu Valley (Andorra) indicated that moderate forest clearing and grazing activities occurred between 8400 and $7800 \mathrm{cal} \mathrm{BP}$, and between 7000 and $6300 \mathrm{cal} \mathrm{BP}$, with the presence of ruderals and pollen providing evidence of woodland clearance. However, the most important threshold of intensified human activity occurred during the Early Bronze Age, at approximately 4100-3600 cal BP. A second threshold occurred between 2050 and 1800 cal BP (during the Iron Age and the Roman Period), 
and a third threshold corresponded to the 16th-18th centuries (during one of the golden periods of the transhumance system) (Miras et al. 2007). Some of these thresholds were also detected in the Perafita Valley (also in Andorra) associated with intense grazing activity during the Mid and Late Neolithic, and the Early and Late Bronze ages (Miras et al. 2010). In the Andorra valleys the finding of small huts dating to the Early Neolithic confirmed the seasonal use of high mountain areas, probably for both hunting and grazing (Orengo et al. 2014). This period was followed by forest recovery and subsequent landscape transformation, as deduced from archaeological data and clear evidence of forest clearing related to occasional fires. Orengo et al. (2014) noted that after 3500 cal BP “some areas remained deforested until today”.

Human-induced fires were also been detected at $1821 \mathrm{~m}$ a.s.l. in Bourg Lake (Central Pyrenees), where clear relationships have been found between fire frequency and anthropogenic pollen indicators (Bal et al. 2011), particularly during the transition from the Bronze Age to the Iron Age (when the recovery of forest was rapid), and during the Roman Period. Since the Roman Period, "fires were used to maintain already open spaces” (Bal et al. 2011). Evidence of early landscape transformation was found in the Upper Noguera Pallaresa Valley, where intensification of human activity during the Bronze and Iron ages and the Roman Period were deduced from the presence of numerous charcoal fragments, particularly during the Middle Ages, when a decline in the altitude of the treeline was detected (Cunill et al. 2012). A sedimentary sequence from Basa de la Mora Lake (1914 m a.s.l.) revealed a decrease in the total arboreal pollen between 4500 and 3900 cal BP (Pérez-Sanz et al. 2013), coinciding with the first deforestation detected in Tramacastilla Lake by Montserrat (1992). Analysis of the Basa de la Mora Lake sequence suggests that anthropogenic pressure was negligible until ca. 1700 yr BP, when fire dynamics intensified (Lasheras-Álvarez et al. 2013), and particularly since $1150 \mathrm{yr}$ BP, with clear evidence of forest management during the Medieval Climate Anomaly (900-1300 AD).

In a review of fire activity in the Mediterranean basin, Vannière et al. (2011) noted that charcoal records during the Mid Holocene "Thermal Maximum" (approximately 7500-4000 cal yr BP) suggest an increase in fire, and that "human influence on regional fire activity became increasingly important after c. 4000-3000 cal. BP”. Walsh et al. (2014) detected four stages of landscape change in the French Alps (the Mesolithic, the Chalcolithic/Bronze Age, the Iron Age and Roman Period, and the post-Medieval period), including forest clearance close to the treeline for hunting, and 
progressive intervention in the subalpine belt to establish the transhumant system. Roepke and Krause (2013) detected four phases of human activity in the French Alps, including the Early to Middle Bronze Age, the Late Iron Age, the Early Middle Ages and the High Middle Ages. Guiguet-Covex et al. (2011) confirmed that the extensive grasslands in European alpine landscapes are the consequence of increasing grazing pressure from 5500 cal yr BP, and particularly since the mid Bronze Age, as demonstrated by a large number of studies in Austria and Switzerland. Colombaroli et al. (2013) arrived at the same conclusions for the central Swiss Alps (Mont d'Orge Lake), and noted that the first forest clearances involved slash-and-burn practices that affected small patches, contributing "to the establishment of a more diversified and fragmented landscape"; this suggests a natural feedback for the occurrence of more small localized fires. A study of sedimentary sequences from four Swiss lakes also detected distinct phases of forest clearance and intensified land use, particularly during the Bronze Age, the Late Iron Age, the Roman Period and the early Middle Ages (Tinner et al. 2003). A high resolution multiproxy study (Dietre et al. 2014) of a 177 cm-long radiocarbon dated peat-bog in the Silvretta Massif (Switzerland/Austria) confirmed that "the exploitation of alpine landscape resources (cultivation of cereals in the valley) and livestock grazing (in the subalpine and alpine areas) has therefore a long tradition going back at least for 6200 years”. In southern Switzerland the occurrence of charcoal peaks was preceded by changes in pollen record, indicating human activity (Tinner et al. 1999). Reconstruction of fire variability at $2343 \mathrm{~m}$ a.s.l. in the Gouillé Rion, Swiss Alps, demonstrated the combined effects of climate variability and human activity. This showed that moderate fires occurred during the first half of the Holocene, but a clear increase occurred during the Chalcolithic and the Bronze Age, when the altitude of the timberline declined by several hundred meters (Colombaroli et al. 2010). Open areas were also found to have been present at high altitudes during the Bronze Age, which is a sign of human-induced subalpine grassland development. Many studies have reported that the timberline was in general located more than $300 \mathrm{~m}$ above its current position (Dietre et al. 2014).

As in other European mountains, forest loss to enlarge the area of subalpine grasslands in the Urbión Mountains favored pastoral activity and the development of transhumant systems. This contributed to the establishment of societies having complex organization and the capacity to use distinct altitudinal belts in different seasons (Anglada et al. 1980; García-Ruiz and Lasanta 1990; García-Ruiz et al. 2015). 
Nevertheless, the substitution of forests by subalpine grasslands had a high environmental cost, resulting in severe erosion caused by gullying and shallow landsliding because of changes in land cover and soil properties (Zavala et al. 2014; García-Ruiz 2015). The location of most of the shallow landslide scars in the subalpine grasslands, and their almost total absence within the forest, confirm that deforestation caused the loss of soil cohesion because of an increase in pore water pressure during periods of intense rainfall or snowmelt (Van Asch et al. 1999). We do not know how often shallow landslides recurred in the study area. However, in similar soils in the Pyrenees, rainstorms corresponding to a return period of more than 25 years have triggered landslides (García-Ruiz et al. 2010) particularly when the preceding soil moisture content was high. This is a very significant problem for soil conservation, because large areas appear to have lost most of their soil (17.8\% of the total area), reducing soil productivity and the sustainability of the system. It is worth determining when generalized shallow landsliding began, but we have insufficient information to address this issue. Shallow landslides probably began with the first forest clearing following Neolithic times, as occurred in the Alps (Guiguet-Covex et al. 2011). We hypothesize that the most dramatic soil erosion impact of deforestation occurred after the Middle Ages, when this process affected a large proportion of the study area. It is also likely that the climatic conditions of the 16th-19th centuries (when the snowpack was deeper) enhanced the occurrence of shallow landslides, as suggested for the Central Pyrenees (García-Ruiz et al. 2010). A sedimentological study of Tramacastilla Lake, in the Spanish Pyrenees (Montserrat, 1992), corroborated the occurrence of moderate soil erosion processes during small deforestation events at ca. $4000 \mathrm{cal}$ yr BP, and dramatic soil erosion activity following generalized fires in the subalpine belt since the Middle Ages.

\section{Acknowledgements}

Support for this research was provided by the projects INDICA (CGL201127753-C02-01 and -02) and DINAMO2 (CGL2012-33063), funded by the Spanish Ministry of Economy and Competitiveness.

\section{References}


Alvera B, Puigdefábregas J (1985) Daily pulses of suspended and dissolved load in snowmelt runoff. Notebooks of Geographic Research (Cuadernos de Investigación Geográfica) 11: 5-20. DOI: http://dxorg/10.18172/cig.938

Anglada S, Balcells E, et al. (1980) The rural life in the Spanish Mountains. Jaca: Institute of Pyrenean Studies. p 108. (In Spanish)

Arnáez Vadillo J (1987) Landforms and processes in hillslope evolution of the Sierra Demanda, Iberian Range. Notebooks of Geographic Research (Cuadernos de Investigación Geográfica) 13: 7-153. DOI: 10.18172/cig.962 (In Spanish)

Bal MC, Pelachs A, Perez-Obiol R, et al. (2011) Fire history and human activities during the last $3300 \mathrm{cal}$ yr BP in Spain’s Central Pyrenees: The case of the Estany of Bourg. Palaeogeography, Palaeoclimatology, Palaeoecology 300 (1-4): 179-190. DOI:10.1016/j.palaeo.2010.12.023

Barrios Gil I (2005) The beginning of Neolithic settlements in the province of La Rioja. Veleia 22: 51-76. (In Spanish)

Berrocal MC, Sebastián López MC, González AU, et al. (2014) Landscape construction and long-term economic practices: an example from the Spanish Mediterranean uplands through rock art archaeology. Journal of Archaeological Method and Theory 21 (3): 589-615. DOI: 10.10007/s10816-012-9157-0

Blarquez O, Carcaillet C, Bremond L, et al. (2010) Trees in the subalpine belt since 11700 cal BP: Origin, expansion and alteration of the modern forest. The Holocene 20: 139-146. DOI: 10.1177/0959683609348857

Camarero Martínez JJ, Gutiérrez Merino E (2008) The response of Pinus uncinata growth to climate in relict populations of the Iberian Range. Zubía Monograph 20: 61-96. (In Spanish)

Carrión JS, Fuentes N, González-Sampériz P, et al. (2007) Holocene environmental change in a montane region of southern Europe with a long history of human settlement. Quaternary Science Reviews 26: 1455-1475. DOI:10.1016/j.quascirev.2007.03.013

Colombaroli D, Vannière B, Emmanuel C, et al. (2008) Fire-vegetation interactions during the Mesolithic-Neolitic transition at Lago dell'Accesa, Tuscany, Italy. The Holocene 18: 679-692. DOI: 10.1177/0959683608091779 
Colombaroli D, Henne PD, Kaltenrieder P, et al. (2010) Species responses to fire, climate and human impact at tree line in the Alps as evidenced by palaeoenvironmental records and a dynamic simulation model. Journal of Ecology 98 (6): 1346-1357. DOI: 10.1177/0959683608091779

Colombaroli D, Beckmann M, van der Knaap WO, et al. (2013) Changes in biodiversity and vegetation composition in the central Swiss Alps during the transition from pristine forest to first farming. Diversity and Distributions 19: 157-170. DOI: 10.1111/j.1472-4642.2012.00930.x

Cunill R, Soriano JM, Bal MC, et al. (2012) Holocene treeline changes on the south slope of the Pyrenees: A pedoanthropological analysis. Vegetation History and Archaeobotany 21 (4-5): 373-384. DOI: 10.1007/s00334-011-0342-y.

Daniau AL, Bartlein PJ, Harrison SP, et al. (2012) Predictability of biomass burning in response to climate changes. Global Biogeochemical Cycles 26 (4): GB4007. DOI: 10.1029/2011GB004249

Diago Hernando M (2002) Mesta and transhumance in Castille (13th to 19th centuries). Madrid: Arc Books. pp 96.

Dietre B, Walser C, Lambers K, et al. (2014) Palaeoecological evidence from Mesolithic to Medieval climatic change and anthropogenic impact on the Alpine flora and vegetation of the Silvretta Massif (Switzerland/Austria). Quaternary International 353: 3-16. DOI:10.1016/j.quaint.2014.05.001

Galop D, Jalut G (1994) Differential human impact and vegetation history in two adjacent Pyrenean valleys in the Ariège basin, southern France, from 3000 BP to the present. Vegetation History and Archaeobotany 3: 225-244.

García de Celis A, Arroyo Pérez P, Gandía Fernández A (2008) Recent changes in the upper forest limit of the Urbión Sierra: forest management, livestock and climate. Zubía Monográfico 20: 97-118. (In Spanish)

García-Ruiz JM (2015) Why geomorphology is a global science. Notebooks of Geographic Research (Cuadernos de Investigación Geográfica) 41 (1): 87-105. DOI:10.18172/cig.2652 (In Spanish)

García-Ruiz JM, Puigdefábregas J (1982) Erosion landforms in the Southern Pyrenees Eocene flysch. Notebooks of Geographic Research (Cuadernos de Investigación Geográfica) 8: 83-126. DOI: 10.18172/cig.897 (In Spanish)

García-Ruiz JM, Lasanta T (1990) Land-use changes in the Spanish Pyrenees. Mountain Research and Development 10 (3): 267-279. 
García-Ruiz JM, Alvera B, del Barrio G, et al. (1990) Geomorphic processes above the timberline in the Spanish Pyrenees. Mountain Research and Development 10 (3): 201-214.

García-Ruiz JM, Valero-Garcés B (1998) Historical geomorphic processes and human activities in the Central Spanish Pyrenees. Mountain Research and Development 18 (4): 309-320. DOI:10.2307/3674096

García-Ruiz JM, Ortigosa L, et al. (1998) Glacial Geomorphology in the Iberian Range. In: Gómez-Ortiz A, Pérez-Alberti A (eds.), Glacial landforms in the Spanish mountains, University of Santiago de Compostela, Santiago de Compostela, pp. 347381. (In Spanish)

García-Ruiz JM, Beguería S, Alatorre LC, et al. (2010) Land cover changes and shallow landsliding in the flysch sector of the Spanish Pyrenees. Geomorphology 124: 250259. DOI:10.1016/j.geomorph.2010.03.036

García-Ruiz JM, López-Moreno JI, et al. (2015) The geoecological effects of Global Change in the Central Spanish Pyrenees: A review at different spatial and temporal scales. Pirineos 170: e012. DOI:10.3989/Pirineos.2015.170005 (In Spanish)

Gil García MJ, Tomás Las Heras R, Nuñez Olivera E, et al. (1995) Pollen analysis of a peatbog deposit in the Cameros Sierra (La Rioja, Spain). Zubía 13: 33-41. (In Spanish)

Gil García MJ, Tomás Las Heras R, Nuñez Olivera E, et al. (1996) Human activity on natural environment in the Cameros Sierra from pollen analysis. Zubía Monograph 8: 29-41. (In Spanish)

Gil García MJ, Dorado Valiño M, Valdeolmillos Rodríguez A, et al. (2002) Late-glacial and Holocene palaeoclimatic record from Sierra Cebollera (northern Iberian Range, Spain). Quaternary International 93-94: 13-18. DOI:10.1016/S1040-6182(02)000034

Gil-Romera G, Carrión JS, Pausas JG, et al. (2010) Holocene fire activity and vegetation response in South-Eastern Iberia. Quaternary Science Reviews 29: 10821092. DOI:10.1016/j.quascirev.2010.01.006

Gil-Romera G, González-Sampériz P, Lasheras-Álvarez L, et al. (2014) Biomassmodulated fire dynamics during the Last Glacial-Interglacial transition at the Central Pyrenees. Palaeogeography, Palaeoclimatology, Palaeoecology 402: 113-124. DOI:10.1016/j.palaeo.2014.03.015 
Gómez-Lobo A (1993) Vegetation history during the last 15,000 years in the Urbion Peaks from pollen analysis. PhD thesis, University of Alcalá de Henares. p 173. (In Spanish)

Gómez Urdáñez J (1986) Subsistence and impoverishment in Camero Viejo at the end of the Modern Ages. Brocar 12: 103-140. (In Spanish)

Gómez-Villar A, Sanjuán Y, García-Ruiz JM, et al. (2014) Sediment organization and adjustment in a torrential reach of the Upper Ijuez River, central Spanish Pyrenees. Notebooks of Geographic Research (Cuadernos de Investigación Geográfica) 40 (1): 191-214. DOI:10.18172/cig.2566

Guiguet-Covex C, Arnaud F, Poulenard J, et al. (2011) Changes in erosion patterns during the Holocene in a currently treeless subalpine catchment inferred from lake sediment geochemistry (Lake Anterne, 2063 m a.s.l., NW French Alps): The role of climate and human activities. The Holocene 21 (4): 651-665. DOI:10.1177/0959683610391320

Hantel M, Maurer C, Mayer D (2012) The snowline climate of the Alps 1961-2010. Theoretical and Applied Climatology 110: 517-537. DOI: 10.1007/s00704-0120688-9

Höllermann P (1985) The periglacial belt of mid-latitude mountains from a geoecological point of view. The Earth (Erdkunde) 39: 259-270.

Lana-Renault N, Alvera B, García-Ruiz JM (2011) Runoff and sediment transport during the snowmelt period in a Mediterranean high-mountain catchment. Arctic, Antarctic, and Alpine Research 43 (2): 213-222. DOI: 10.1657/1938-4246-43.2.213

Lasheras-Álvarez L, Pérez-Sanz A, et al. (2013) History of the fire and vegetation in a Holocene sequence of the Central Pyrenees: La Basa de la Mora lake. Notebooks of Geographic Research (Cuadernos de Investigación Geográfica) 39 (1): 7-95. DOI: 10.18172/cig.2000 (In Spanish)

López de Calle C, Pérez Arrondo C (1995) Radiocarbon dates and settlement phases in the megalithic tombs of Cameros (La Rioja). Notebooks of Prehistory-Archaeology (Cuadernos de Sección Prehistoria-Arqueología) 6:343-360. (In Spanish)

López de Calle C, Tudanca JM (2014) Looking Cameros from Archaeology: attitudes and methodological proposals in landscape interpretation. Berceo 167: 121-175. (In Spanish) 
López de Calle C, Iriarte MJ, Zapata L (2001) Palaeoenvironmental analyses in the Collado del Mallo dolmen (Trevijano, La Rioja). Feasibility and obstacles of plant palaeoecology in dolmenic structures. Zubía Monograph 13: 65-96. (In Spanish)

López-Moreno JI, García-Ruiz JM (2004) Influence of snow accumulation and snowmelt on streamflow in the Central Spanish Pyrenees. Hydrological Sciences Journal 49 (5): 787-802. DOI: 10.1623/hysj.49.5.787.55135

Marlon JR, Bartlein PJ, Carcaillet C, et al. (2009) Climate and human influences in global biomass burning over the past two millennia. Nature Geoscience 1: 697-702. DOI:10.1038/ngeo313

Marlon JR, Bartlein PJ, Daniau AL, et al. (2013) Global biomass burning: a synthesis and review of Holocene paleofire records and their controls. Quaternary Science Reviews 65: 5-25. DOI:10.1016/j.quascirev.2012.11.029

Marty C, Meister R (2012) Long-term snow and weather observations at Weissfluchjoch and its relation to other high-altitude observatories in the Alps. Theoretical and Applied Climatology 110: 573-583. DOI:10.1007/s00704-012-05843

Miras Y, Ejarque A, Riera S, et al. (2007) Holocene dynamics of the Pyrenean vegetation and human settlements in Andorre after the Early Neolithic, according to pollen analysis of the Bosc dels Estanyons peatbog (2180 m, Vall de Madriu, Andorre). Proceedings of Palaeoevolution (Comptes Rendues Palevolution) 6 (4): 291-300. DOI:10.1016/j.crpv.2007.02.005 (In French)

Miras Y, Ejarque A, Orengo H, et al. (2010) Prehistoric impact on landscape and vegetation at high altitudes: An integrated palaeoecological and archaeological approach in the eastern Pyrenees (Perafita valley, Andorra). Plant Biosystems 144 (4): 924-939. DOI:10.1080/11263504.2010.491980

Montserrat J (1992) Glacial and post-glacial climate and vegetation evolution in the Pyrenean south versant: Palinological study. Saragossa: Pyrenean Institute of Ecology. p 147. (In Spanish)

Morales-Molino C, García-Antón M, Morla C (2011) Late Holocene vegetation dynamics on an Atlantic-Mediterranean mountain in NW Iberia. Palaeogeography, Palaeoclimatology, $\quad$ Palaeoecology 302: 323-337. DOI:10.1016/j.palaeo.2011.01.020, 
Moreno Fernández JR (1994) The public woodland in La Rioja during the 18 and 19th centuries: approach to the disorganization of the comunal regime. Logroño: La Rioja Government. p 299. (In Spanish)

Moreno Fernández JR (1996) The transhumant livestock in La Rioja 1752-1865. Una revisión bibliográfica y cuantitativa. Brocar 20: 277-302. (In Spanish)

Ninot JM, Batllori E, Carrillo E, et al. (2008) Timberline structure and limited tree recruitment in the Catalan Pyrenees. Plant Ecology \& Diversity 1 (1): 47-57. DOI: $10.1080 / 17550870802260764$

Orengo HA, Palet JM, Ejarque A, et al. (2014) Shifting occupation dynamics in the Madriu-Perafita-Claror valleys (Andorra) from the early Neolithic to the Chalcolithic: The onset of high mountain cultural landscapes. Quaternary International 353: 140-152. DOI:10.1016/j.quaint.2014.01.035

Pérez-Díaz S, López-Sáez JA, Galop D (2014) Vegetation dynamics and human activity in the Western Pyrenean Region during the Holocene. Quaternary International 364: 65-77. Doi:10.1016/j.quaint.2014.10.019

Pérez-Sanz A, González-Sampériz P, Moreno A, et al. (2013) Holocene climate variability, vegetation dynamics and fire regime in the central Pyrenees: The Basa de la Mora sequence (NE Spain). Quaternary Science Reviews 73: 149-169. DOI:10.1016/j.quascirev.2013.05.010

Reimer P, Bard E, Bayliss A, et al. (2013) IntCal13 and Marine13 radiocarbon age calibration curves 0-50,000 Years cal BP. Radiocarbon 55 (4): 1869-1887. DOI:10.2458/azu_js_rc.55.16947

Roepke A, Krause R (2013) High montane-subalpine soils in the Montafon Valley (Austria, northern Alps) and their link to land-use, fire and settlement history. Quaternary International 308-309: 178-189.DOI:10.1016/j.quaint.2013.01.022

Rojo Guerra MA, Peña L, Royo JI, et al.(2013) Transhumant shepherds of the Old Neolithic in a high mountain environment: Chrono-cultural sequence at Els Trocs Cave (San Feliú de Veri, Huesca). BSAA Archaeology 79: 9-55. (In Spanish)

Rull V, González-Sampériz P, Corella JP, et al. (2011) Vegetation changes in the southern Pyrenean flank during the last millennium in relation to climate and human activities: the Moncortès lacustrine record. Journal of Paleolimnology 46 (3): 387404. DOI:10.1007/s10933-010-9444-2 
Sanjuán Y, Gómez-Villar A, Nadal-Romero E, et al. (2014) Linking land cover changes in the sub-alpine and montane belts to changes in a torrential river. Land Degradation \& Development, DOI: 10.1002/ldr.2294

Schmidt R. Koinig KA, Thompson R, et al. (2002) A multi proxy core study of the last 7000 years of climate and alpine land-use impacts on an Austrian mountain lake (Unter Landschitzsee, Niedere Tauern). Palaeogeography, Palaeoclimatology, Palaeoecology 187 (1-2): 101-120. DOI:10.1016/S0031-0182(02)00511-4

Sharma V, Mishra VD, Joshi PK (2013) Implications of climate change on streamflow of a snow-fed river system of the Northwest Himalaya. Journal of Mountain Science 10 (4): 574-587. DOI: 10.1007/s11629-013-2667-8

Sobrón García I (1987) Approach to the vegetation belts in the mountains of La Rioja. Geographic Studies (Estudios Geográficos) 189: 659-680. (In Spanish)

Stewart IT (2009) Changes in snowpack and snowmelt runoff for key mountain regions. Hydrological Processes 23 (1): 78-94. DOI:10.1002/hyp.7128

Stuiver M, Reimer J (1993) Extended 14C data base and revised CALIB 3.014 C age calibration program. Radiocarbon 35: 215-230.

Tinner W, Hubschmid P, Wehrli M, et al. (1999) Long-term forest fire ecology and dynamics in southern Switzerland. Journal of Ecology 87: 273-289.

Tinner W, Lotter AF, Ammann B, et al. (2003) Climate change and contemporaneous land-use phases north and south of the Alps 2300 BC to 800 AD. Quaternary Science Reviews 22: 1447-1460. DOI:10.1016/S0277-3791(03)00083-0

Van Asch TWJ, Buma J, Van Beek LPH (1999) A view on some hydrological triggering systems in landslides. Geomorphology $30 \quad(1-2): \quad 25-32$. DOI:10.1016/S0169-555X(99)00042-2

Vannière B, Power MJ, Roberts N, et al. (2011) Circum-Mediterranean fire activity and climate changes during the mid-Holocene environmental transition (8500-2500 cal. BP). The Holocene 21 (1): 53-73. DOI:10.1177/0959683610384164

Vegas J (2007) Characteristics of the Upper Pleistocene-Holocene climate events through the sedimentological study of the Grande Lake (Sierra Neila, NO Sistema Ibérico). Journal of the Spanish Geological Society (Revista de la Sociedad Geológica de España) 20 (1-2): 53-70. (In Spanish)

Walsh K, Court-Picon M, de Beaulieu JL, et al. (2014) A historical ecology of the Ecrins (Southern French Alps): Archaeology and palaeoecology of the Mesolithic to 
the Medieval period. Quaternary International 353: 52-73. DOI:10.1016/j.quaint.2013.08.060

Zavala LM, de Celis R, Jordán A (2014) How wildfires affect soil properties. A brief review. Notebook of Geographic Research (Cuadernos de Investigación Geográfica) 40 (2): 311-331. DOI: http://dx.doi.org/10.18172/cig.2522 

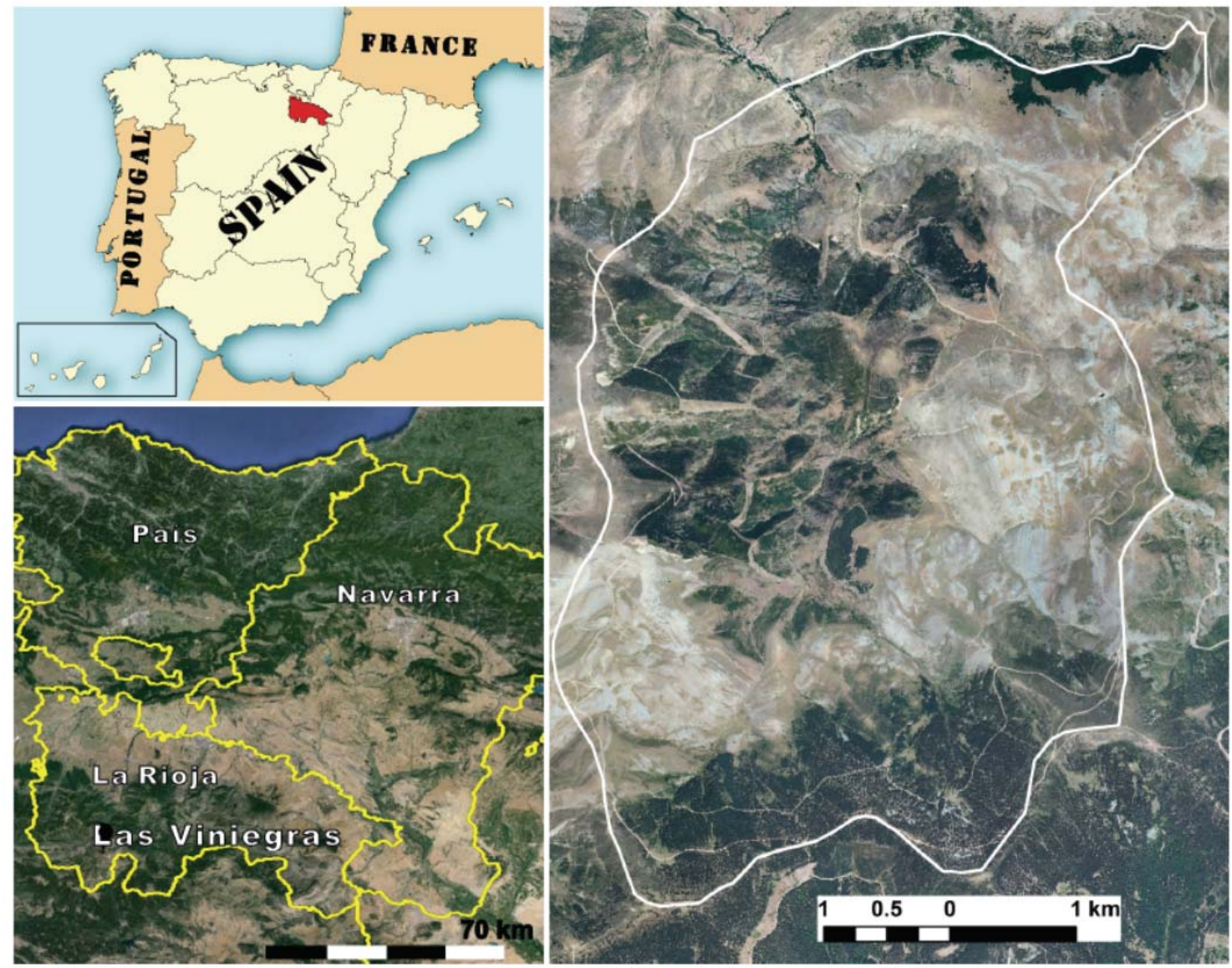

Figure 1 The location of the study area at distinct scales within the Iberian Peninsula, Southwestern Europe. Coordinates of the center of the study area are $42^{\circ} 3^{\prime} 58.68^{\prime \prime}$ N, 20 $49^{\prime} 33.4^{\prime \prime}$ W.
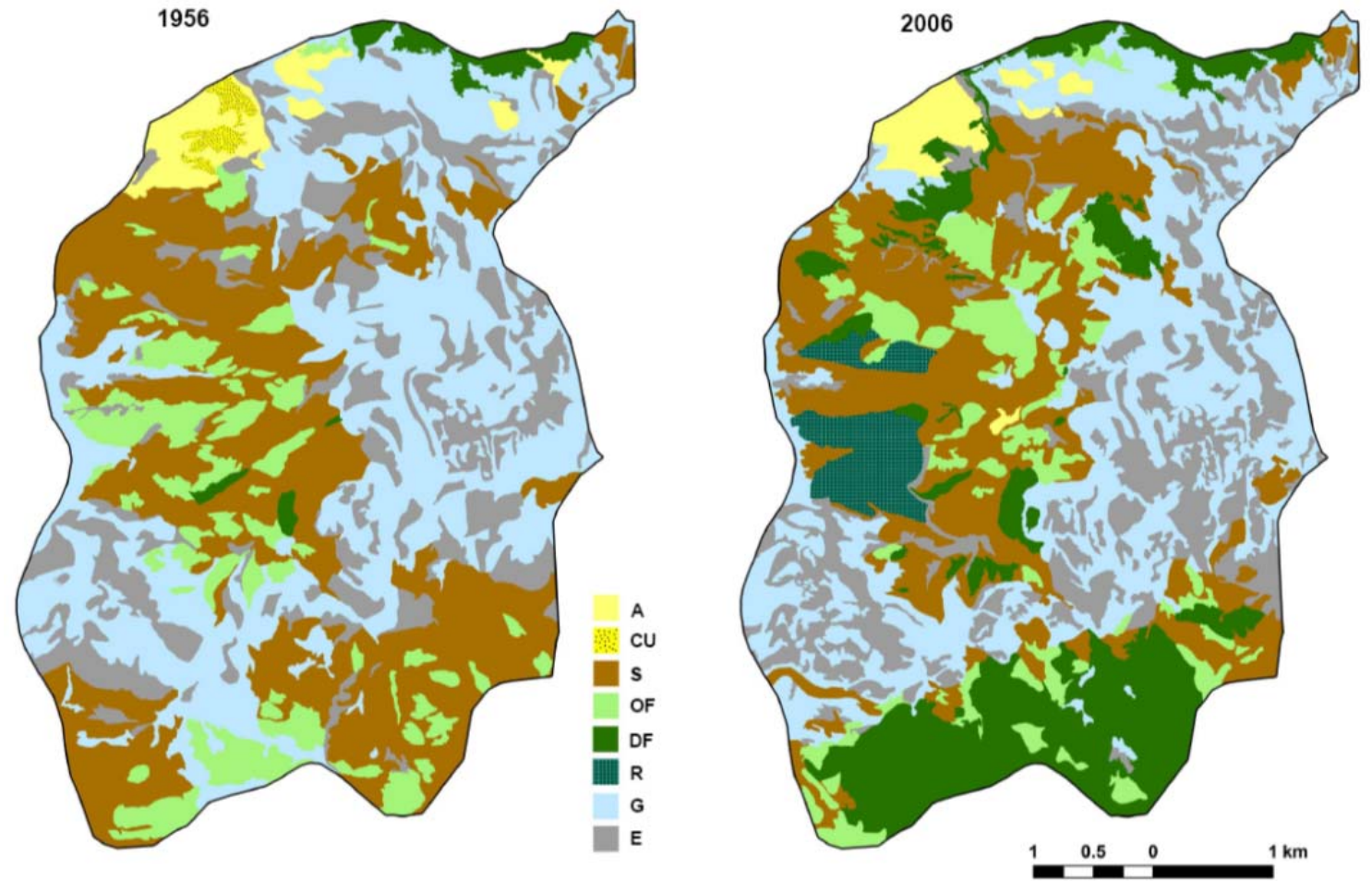

Figure 2 Land cover maps of the study area in 1956(a) and 2006(b). A: Abandoned fields; CU: cultivated fields; S: Shrublands; OF: Open forest; DF: Dense forest; G: Grasslands; E: Eroded areas; R: Afforested areas. 


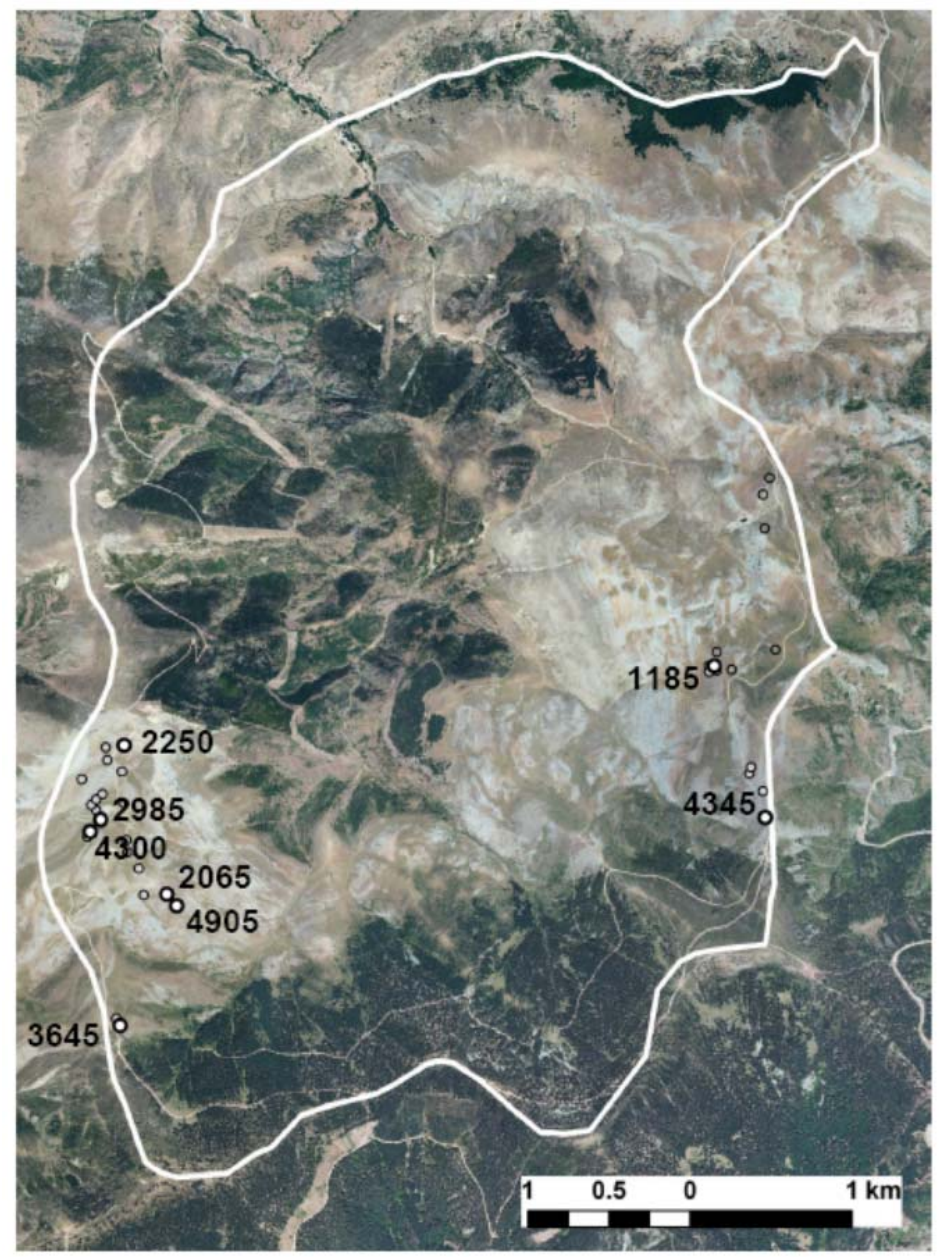

Shallow landslide scars where no charcoal was found

O Shallow landslide scars with charcoal fragments in the soil profile

2250 Radiocarbon $14 \mathrm{C}$ ages (cal. yr BP) of charcoal fragments

Figure 3 Location of the whole studied profiles in the subalpine belt of the Ormazal Valley, with indication of the soil samples analysed indicating the eight points which provided enough charcoal fragments to date. 


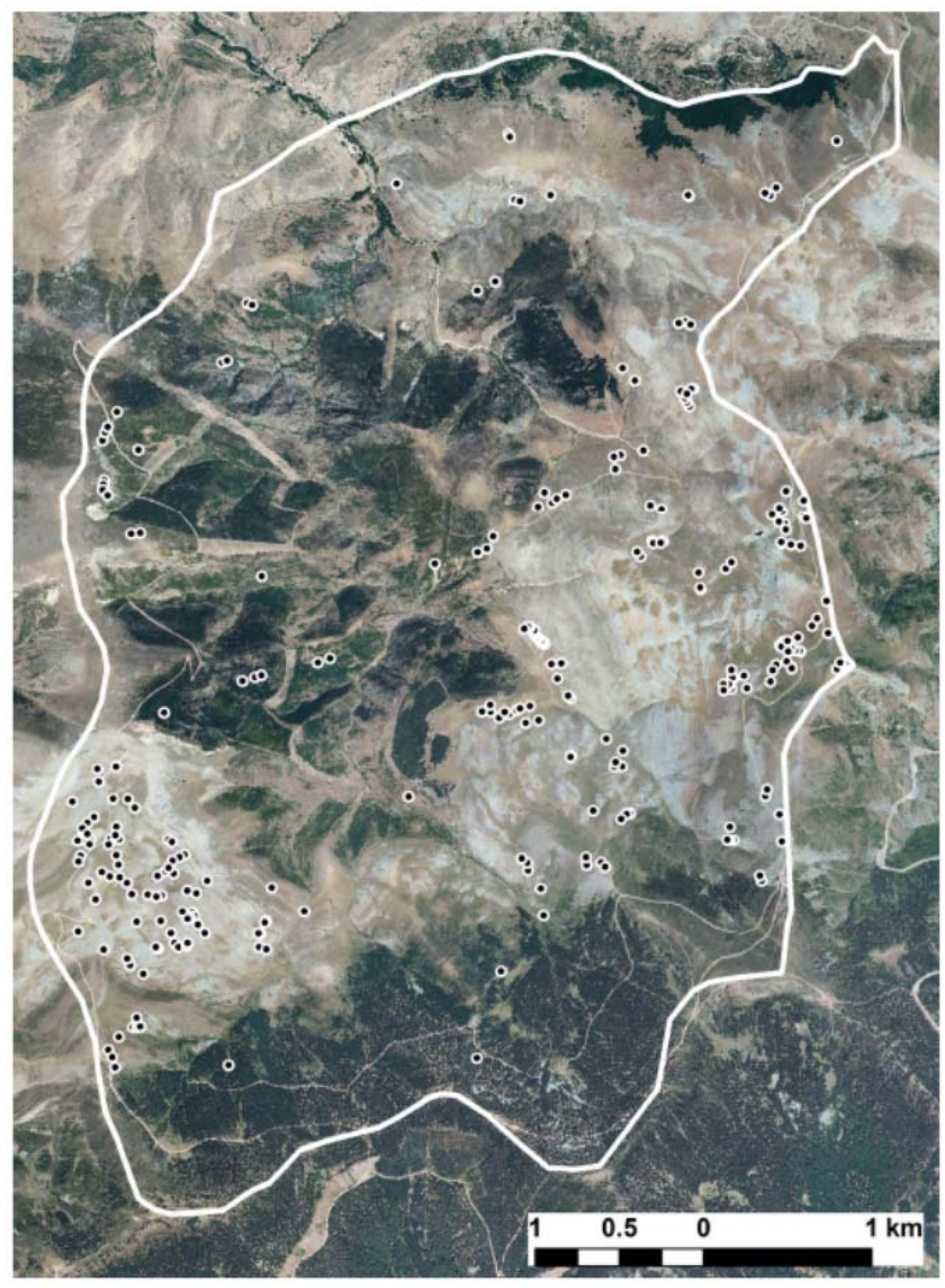

Figure 4 Location of the landslide scars in the Ormazal Valley, according to the 2006 ortophoto.

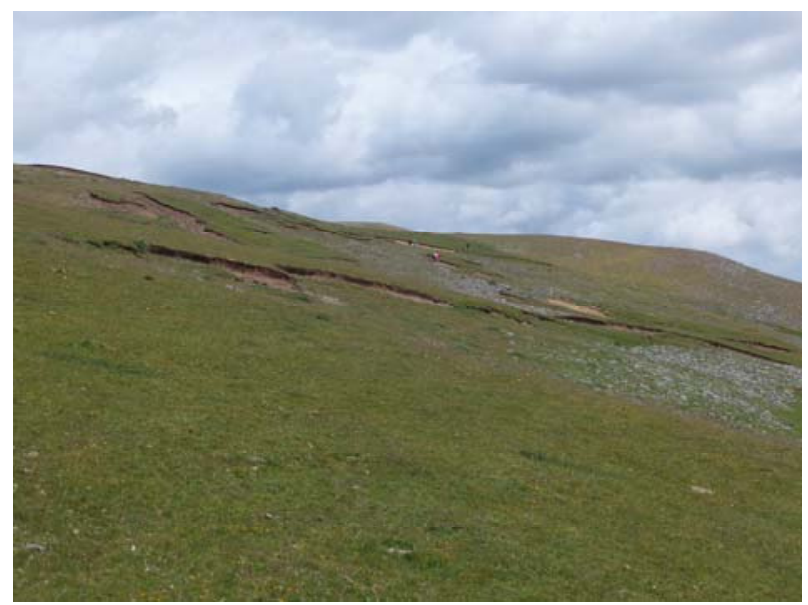

Figure 5 Landslide scars in the subalpine belt of the Ormazal Valley, Urbión Mountains. 


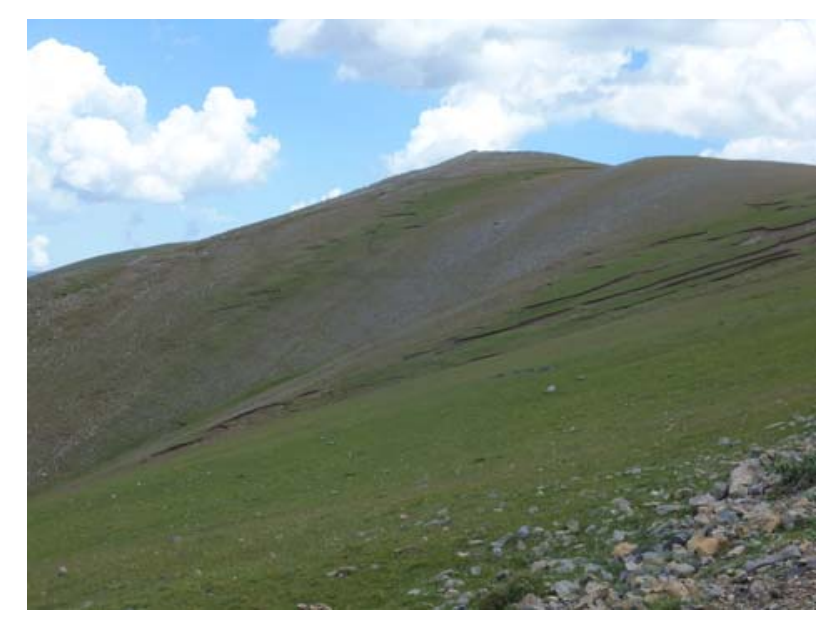

Figure 6 Large aggregated landslides in the Ormazal Valley, Urbión Mountains, with the steepest slopes already eroded.

Table 1 Land cover and soil uses in 1956 and 2006

\begin{tabular}{|l|l|l|l|l|}
\hline Abandoned fields & 71.28 & 2.9 & 59.23 & 2.4 \\
\hline Cultivated fields & 18.31 & 0.7 & & \\
\hline Dense forest & 43.22 & 1.8 & 397.94 & 16.3 \\
\hline Open forest & 240.47 & 9.8 & 196.41 & 8.0 \\
\hline Grasslands & 836.18 & 34.1 & 674.24 & 27.6 \\
\hline Shrublands & 780.55 & 31.9 & 585.69 & 23.9 \\
\hline Erodedareas & 450.39 & 18.4 & 434.84 & 17.8 \\
\hline Afforestation & 8.43 & 0.4 & 100.47 & 4.0 \\
\hline Total & 2448.83 & & 2448.83 & \\
\hline
\end{tabular}

Table 2 Chronological data of the charcoal samples shown in Figure 3

\begin{tabular}{|c|c|c|c|c|c|c|c|c|c|c|c|c|}
\hline $\begin{array}{l}\text { Lab } \\
\text { code }\end{array}$ & $\begin{array}{l}\text { Sample } \\
\text { name }\end{array}$ & $\begin{array}{l}\text { Alt. } \\
\text { (m a.s.l.) }\end{array}$ & $\mathrm{d}^{13} \mathrm{C}$ & Frac. & \pm & $d^{14} C$ & \pm & ${ }^{14} \mathrm{C}$ Age & \pm & $\begin{array}{l}\text { Lower cal } \\
\text { range } \\
\text { (2sigma) }\end{array}$ & $\begin{array}{l}\text { Upper cal } \\
\text { range } \\
\text { (2sigma) }\end{array}$ & $\begin{array}{l}\text { Mean cal } \\
\text { BP } \\
\text { (2sigma) }\end{array}$ \\
\hline 169725 & VIN 14B 8 & 1742 & -25 & 0.7555 & 0.0031 & -244.5 & 3.1 & 2250 & 35 & 2154 & 2272 & 2234 \\
\hline 169726 & VIN 18B 11 & 1794 & -25 & 0.7735 & 0.0026 & -226.5 & 2.6 & 2065 & 30 & 1966 & 2119 & 2034 \\
\hline 169727 & & 1848 & -25 & 0.6354 & 0.0028 & -364.6 & 2.8 & 3645 & 35 & 3871 & 4014 & 3962 \\
\hline 169728 & & 1755 & -25 & 0.5821 & 0.0020 & -417.9 & 2.0 & 4345 & 30 & 4848 & 4973 & 4911 \\
\hline 169729 & & 1859 & -25 & 0.8626 & 0.0030 & -137.4 & 3.0 & 1185 & 30 & 1051 & 1182 & 1116 \\
\hline 169730 & VIN 19B 5 & 1847 & -25 & 0.5430 & 0.0024 & -457.0 & 2.4 & 4905 & 40 & 5589 & 5663 & 5630 \\
\hline 169731 & VIN 2B & 1762 & -25 & 0.5855 & 0.0021 & -414.5 & 2.1 & 4300 & 30 & 4829 & 4892 & 4858 \\
\hline 169732 & VIN 4 & 1738 & -25 & 0.6895 & 0.0023 & -310.5 & 2.3 & 2985 & 30 & 3064 & 3246 & 3162 \\
\hline
\end{tabular}

Frac. $=$ Fraction modern 